\title{
Faktor - Faktor yang Memengaruhi Perilaku Konsumen Produk Kosmetik Halal di Kota Bogor
}

\author{
Factors Affecting Consumer Behaviour on Halal Cosmetic Product in Bogor \\ Stevia Septiani ${ }^{1 *}$, Retno Indraswari $^{1}$ \\ ${ }^{1}$ Departemen Manajemen, Fakultas Ekonomi dan Manajemen, IPB Kampus Dramaga Bogor 16680
}

\begin{abstract}
The halal cosmetics industry has a very potential trend both globally and nationally. In Indonesia, the halal cosmetics industry is one of the industries that contribute to the improvement of the Islamic economy. Along with the development of public knowledge about organic products that are environmentally friendly and do not contain animal ingredients, the demand of halal cosmetics products are increase.Unfortunately, the great potential of the halal industry cannot be used properly by local brand. This study aims to analyze some factors that related in halal purchasing decisions. The primary data collection in this study was carried out by purposive sampling method which is women workers. Data processing methods include descriptive analysis and Structural Equation Modeling (SEM) analysis with Partial Least Squares (PLS) approach. The results of SEM analysis shown that the Psychological latent variable has a direct positive effect to Purchasing, with a path coefficient of 0.603. Psychological aspects are a relevant factor in the halal cosmetic purchasing as halal using motifs could be reflect fulfillment an attractive confession as female workers.
\end{abstract}

Keywords: halal cosmetics industry, consumer behaviour, structural equation modeling, partial least square

\section{ABSTRAK}

Prospek industri kosmetik halal baik dalam lingkup global maupun nasional memiliki trend yang sangat potensial. Di Indonesia, industri kosmetik halal menjadi salah satu industri yang berkontribusi pada peningkatan ekonomi syariah. Seiring dengan berkembangnya pengetahuan masyarakat mengenai produk organik yang ramah terhadap lingkungan serta tidak mengandung bahan hewani, maka produk-produk kosmetika halal semakin diminati. Ironisnya, potensi besar industri kosmetik halal nasional belum dapat dimanfaatkan dengan baik oleh para pemain lokal. Sehingga penelitian ini bertujuan untuk menganalisis profil konsumen produk kosmetik halal, menganalisis karakteristik pembelian konsumen produk kosmetik halal dan menganalisis faktor-faktor yang berpengaruh pada keputusan pembelian kosmetik halal. Pengumpulan data primer pada penelitian ini dilakukan dengan metode purposive sampling yang mana peneliti menentukan judgment terhadap pemilihan responden agar sesuai dengan target pasar mayoritas industri kosmetik yaitu wanita pekerja. Metode pengolahan data yang digunakan antara lain adalah analisis deskriptif dan analisis Structural Equation Modeling (SEM) dengan pendekatan Partial Least Squares (PLS). Diketahui bahwa variabel laten Psikologis memiliki pengaruh positif langsung terhadap Pembelian, dengan koefisien jalur sebesar 0,603. Faktor psikologis menjadi faktor yang berpengaruh pada pembelian kosmetik berlabel halal dikarenakan motif penggunaan kosmetik mampu menunjukkan pemenuhan kebutuhan pengakuan yakni penampilan yang menarik sebagai wanita pekerja.

Kata Kunci: industri kosmetik halal, perilaku konsumen, structural equation modeling, partial least square

*Corresponding author

Alamat e-mail: steviaipb@gmail.com 


\section{PENDAHULUAN}

Industri kosmetik halal merupakan salah satu industri yang memiliki potensi besar dalam peningkatan ekonomi syariah. Hal ini sesuai dengan pernyataan Deputi Gubernur Senior Bank Indonesia yang menyebutkan bahwa setelah beberapa tahun mengalami perlambatan, ekonomi dan keuangan syariah Indonesia memiliki harapan untuk tumbuh secara berkelanjutan melalui potensi pengembangan industri halal seperti halal food, halal travel, islamic fashion, halal pharmaceutical \& cosmetics serta Islamic entertainment (ISEO 2018). Secara global prospek bisnis pada industri kosmetik halal satu tahun terakhir cukup baik, dimana data pada State of The Global Islamic Economy Report 2017 - 2018 menyebutkan pertumbuhannya mencapai 8,10 persen. Berdasarkan Global Islamic Economy Indicator (GIEI) Negara Indonesia termasuk pada Top 10 pada industri farmasi dan kosmetika halal. Menurut Survey Bizteka (2015), pertumbuhan pasar industri kosmetik di Indonesia rata-rata mencapai 9,67 persen per tahun dan terus meningkat selama enam tahun terakhir. Nilai penjualan industri kosmetik di Indonesia dapat dilihat pada Gambar 1.

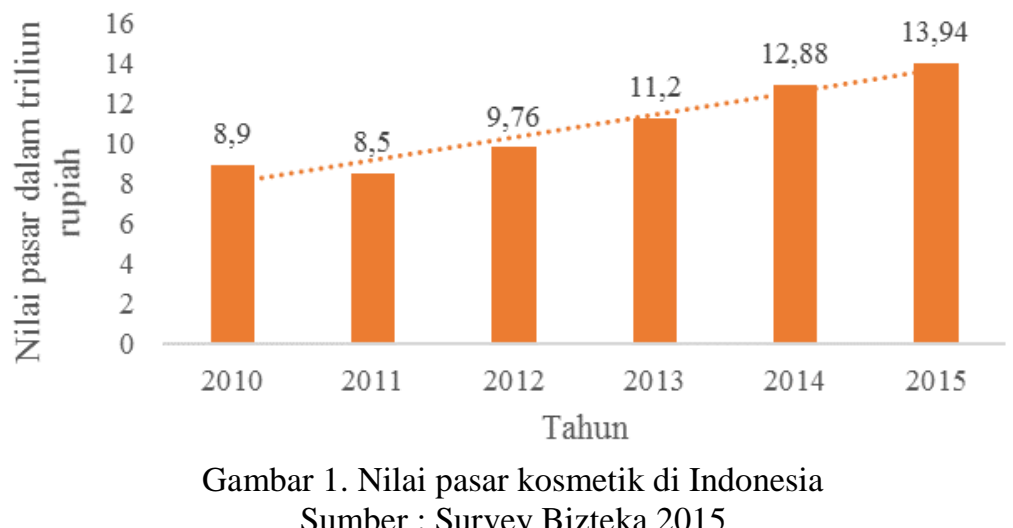

Jurnal Manajemen dan Organisasi (JMO),

Vol. 9, No. 1, April 2018, Hal. 59-73 
mapping karakteristik industri kosmetik halal. Briliana dan Viana (2016) menyebutkan bahwa perilaku konsumen memiliki pengaruh positif terhadap minat beli produk kosmetik halal. Agar didapatkan gambaran lebih mendalam maka penelitian mengenai indikator-indikator yang memengaruhi perilaku konsumen pada produk kosmetik halal perlu dilakukan. Hal yang mendasari Kota Bogor dipilih sebagai objek penelitian adalah karena Kota Bogor diwacanakan menjadi salah satu kota halal di Indonesia (tribunewsBogor.com 2016).

\section{TINJAUAN PUSTAKA}

\section{Perilaku Konsumen}

Sumarwan (2011) menyatakan bahwa perilaku konsumen adalah semua kegiatan, tindakan, serta proses psikologis yang mendorong tindakan tersebut pada saat sebelum membeli, ketika membeli, menggunakan, menghabiskan produk dan jasa setelah melakukan hal-hal di atas atau kegiatan mengevaluasi. Menurut Kotler dan Armstrong (2008), perilaku pembelian konsumen mengacu pada perilaku pembelian konsumen akhir perorangan dan rumah tangga yang membeli barang dan jasa untuk konsumsi pribadi. Perilaku konsumen dipengaruhi oleh beberapa faktor :

1. Faktor Budaya

Budaya adalah penyebab keinginan dan perilaku seseorang yang paling dasar. Pemasar selalu berusaha menemukan perubahan budaya untuk menemukan produk baru yang mungkin diinginkan orang. Masing-masing budaya mengandung subbudaya yang lebih kecil atau kelompok orang yang berbagi sistem nilai berdasarkan pengalaman hidup dan situasi yang umum. Subbudaya meliputi kebangsaan, agama, kelompok ras, dan daerah geografis. Dalam faktor budaya juga terdapat kelas sosial yaitu pembagian masyarakat yang relatif permanen dan berjenjang di mana anggotanya berbagi nilai, minat, dan perilaku yang sama. Kelas sosial ditentukan oleh pekerjaan, pendapatan, pendidikan, kekayaan, dan varabel lain.

2. Faktor Sosial

Faktor sosial yang mempengaruhi perilaku konsumen antara lain kelompok kecil, keluarga, serta peran dan status sosial konsumen. Perilaku konsumen dipengaruhi oleh banyak kelompok kecil. Kelompok yang mempunyai pengaruh langsung dan tempat di mana seseorang menjadi anggotanya disebut kelompok keanggotaan. Sebaliknya, kelompok referensi bertindak sebagai titik perbandingan dalam membentuk sikap seseorang. Konsumen sering kali dipengaruhi oleh kelompok referensi di mana mereka tidak menjadi anggotanya. Peran dan status konsumen juga mempengaruhi perilaku pembelian. Peran terdiri dari kegiatan yang diharapkan dilakukan seseorang sesuai dengan orang-orang sekitarnya, dimana dalam setiap peran terdapat status yang mencerminkan nilai umum yang diberikan masyarakat.

3. Faktor Pribadi

Keputusan konsumen juga dipengaruhi oleh karakteristik pribadi seperti usia dan tahap siklus hidup pembeli, pekerjaan, situasi ekonomi, gaya hidup, serta kepribadian dan konsep diri. Konsumen akan mengubah barang dan jasa yang dibeli seiring dengan tahap hidup dan usianya. Orang yang berasal dari subbudaya, kelas sosial, dan pekerjaan yang sama mungkin mempunyai gaya hidup yang berbeda. Gaya hidup terdiri dari dimensi activities, interest, dan opinions yang menampilkan seluruh pola tindakan pembelian konsumen. Konsep gaya hidup dapat membantu pemasar untuk memahami nilai konsumen yang berubah dan bagaimana gaya hidup mempengaruhi perilaku pembelian.

4. Faktor Psikologis

Empat faktor psikologis utama yang mempengaruhi pembelian konsumen adalah motivasi, persepsi, pembelajaran, serta keyakinan dan sikap. Seseorang senantiasa mempunyai banyak kebutuhan, salah satunya adalah kebutuhan psikologis yang timbul dari kebutuhan akan pengakuan, penghargaan, atau rasa memiliki. Kebutuhan menjadi motif ketika kebutuhan tersebut mencapai tingkat intensitas kuat atau disebut dengan motivasi. Konsumen yang termotivasi akan siap bertindak. Cara orang tersebut bertindak dipengaruhi oleh persepsi dirinya dimana dia memilih, mengatur, dan menginterpretasikan informasi untuk membentuk gambaran yang berarti. Ketika konsumen bertindak, mereka belajar. Pembelajaran

Jurnal Manajemen dan Organisasi (JMO), Vol. 9, No. 1, April 2018, Hal. 59-73 
menggambarkan perubahan dalam perilaku seseorang yang timbul dari pengalaman. Melalui pelaksanaan dan pembelajaran, seseorang mendapatkan keyakinan dan sikap. Keyakinan didasarkan pada pengetahuan nyata, pendapat atau kepercayaan. Keyakinan membentuk citra produk dan merek yang mempengaruhi perilaku pembelian. Sedangkan, sikap menggambarkan evaluasi, perasaan, dan kecenderungan yang relatif konsisten. Sikap seseorang memiliki pola, dan untuk mengubah sikap seseorang diperlukan penyesuaian yang rumit. Oleh karena itu, perusahaan harus selalu berusaha menyesuaikan produknya dengan sikap yang sudah ada daripada mengubah sikap.

\section{Halal Kosmetik}

Menurut UUD Republik Indonesia Nomor 33 Tahun 2014, untuk menjamin setiap pemeluk agama beribadah dan menjalankan ajaran agamanya, negara berkewajiban memberikan perlindungan dan jaminan tentang kehalalan produk yang dikonsumsi dan digunakan masyarakat. Oleh karena itu, jaminan penyelenggaraan produk halal bertujuan memberikan kenyamanan, kemanan, keselamatan, dan kepastian ketersediaan produk halal bagi masyarakat dalam mengonsumsi dan menggunakan produk, serta meningkatkan nilai tambah bagi pelaku usaha untuk memproduksi dan menjual produk halal. Salah satu produk yang digunakan dan dibeli oleh masyarakat terutama wanita adalah kosmetik. Kehalalan produk kosmetik ditentukan dari bahan baku dan proses produksinya. Walaupun ketentuan kehalalan produk sudah diatur dalam Undang-Undang No 33 Tahun 2014, namum belum ada daftar bahan baku positif dan negatif khusus untuk produk kosmetika, sehingga penentuan halal produk kosmetik mengikuti syarat secara umum yaitu :

1. Tidak mengandung babi dan bahan yang berasal dari babi.

2. Tidak mengandung khamr dan produk turunannya.

3. Semua bahan asal hewan harus berasal dari hewan halal yang disembelih menurut tata cara syari'at islam.

4. Tidak mengandung bahan-bahan lain yang diharamkan atau tergolong najis seperti: bangkai, darah, bahan-bahan yang berasal dari organ manusia, kotoran dan lain sebagainya.

5. Semua tempat penyimpanan, tempat penjualan, pengolahan, tempat pengolahan dan alat transportasi untuk produk halal tidak boleh digunakan babi atau barang tidak halal lainnya. Jika fasilitas tersebut pernah digunakan untuk babi atau barang tidak halal lainnya dan kemudian akan digunakan untuk produk halal, maka terlebih dahulu harus dibersihkan sesuai dengan tata cara yang diatur menurut syar'at islam. Penggunaan fasilitas produksi untuk produk halal dan tidak halal bergantian tidak diperbolehkan.

Produsen kosmetik yang telah melakukan sertifikasi halal dan memenuhi syarat, kemudian akan memiliki izin untuk mencantumkan label halal pada kemasan produknya. Menurut tirto.id, nilai pasar kosmetik di Indonesia meningkat rata-rata sebesar 30 USD dari tahun 2013 sampai tahun 2015 yang berarti pasar kosmetik halal di Indonesia merupakan pasar potensial. Walaupun pasar kosmetik halal terus mengalami peningkatan, perusahaan yang telah memliki sertifikat halal masih sedikit. Menurut data Persatuan Perusahaan Kosmetik Indonesia (Perkosmi), baru sembilan persen perusahaan yang bersertifikasi halal. Sehingga masih banyak produsen yang belum mendaftarkan dan memiliki sertifikat halal.

Jurnal Manajemen dan Organisasi (JMO),

Vol. 9, No. 1, April 2018, Hal. 59-73

\section{Structural Equation Modeling Analysis}

Menurut Sugiarto (2006), model persamaan struktural (Structural Equation Modeling) adalah suatu teknik statistik yang mampu menganalisis variabel laten, variabel indikator, dan kesalahan pengukuran secara langsung. Menurut Ghozali dan Latan (2015), Structural Equation Modeling (SEM) adalah suatu teknik analisis multivariat yang dapat menguji hubungan antara variabel yang kompleks untuk memperoleh gambaran menyeluruh mengenai suatu model. Pada penelitian ini metode yang digunakan adalah analisis SEM dengan pendekatan Partial Least Square (PLS). Analisis SEM PLS biasanya terdiri dari dua sub model yaitu model pengukuran (outer model) dan model struktural (inner model). SEM PLS bertujuan mencari hubungan linier prediktif antar variabel. 


\section{METODOLOGI}

\section{Kerangka Pemikiran}

Industri kosmetik halal memiliki potensi yang baik untuk mendukung keberlanjutan ekonomi syariah di Indonesia. Hal ini terlihat dari Survey Bizteka (2015), bahwa nilai penjualan industri pasar kosmetik di Indonesia dari tahun 2010 sampai 2015 memiliki trend positif. Seiring dengan berkembangnya pengetahuan masyarakat mengenai produk organik yang ramah terhadap lingkungan serta tidak mengandung bahan hewani, maka produk-produk kosmetika halal semakin diminati. Sebagai Negara dengan populasi muslim terbesar di dunia, Indonesia memiliki potensi tidak hanya menjadi pasar utama tetapi juga produsen utama produk halal. Ironisnya, potensi besar industri kosmetik halal nasional belum dapat dimanfaatkan dengan baik oleh para pemain lokal. Pertumbuhan industri kosmetik dalam negeri baru mencapai $25-30$ persen dari total nilai perdagangan domestik (industri.kontan.co.id 2017) dengan kata lain masih didominasi oleh kontribusi merek multinasional. Dalam rangka meningkatkan peran pemain lokal dalam industri kosmetik halal yang prospektif, diperlukan kajian-kajian ilmiah baik dari sudut pandang produsen maupun konsumen guna membuat mapping karakteristik industri kosmetik halal. Penelitian ini melakukan kajian pada karakteristik konsumen dengan analisis deskriptif, karakteristik pembelian dengan analisis deskriptif, serta membuat model pengembangan perilaku konsumen pada produk kosmetik halal melalui analisis Structural Equation Modeling dengan pendekatan Partial Least Squar. Kerangka pemikiran disajikan pada Gambar 2.

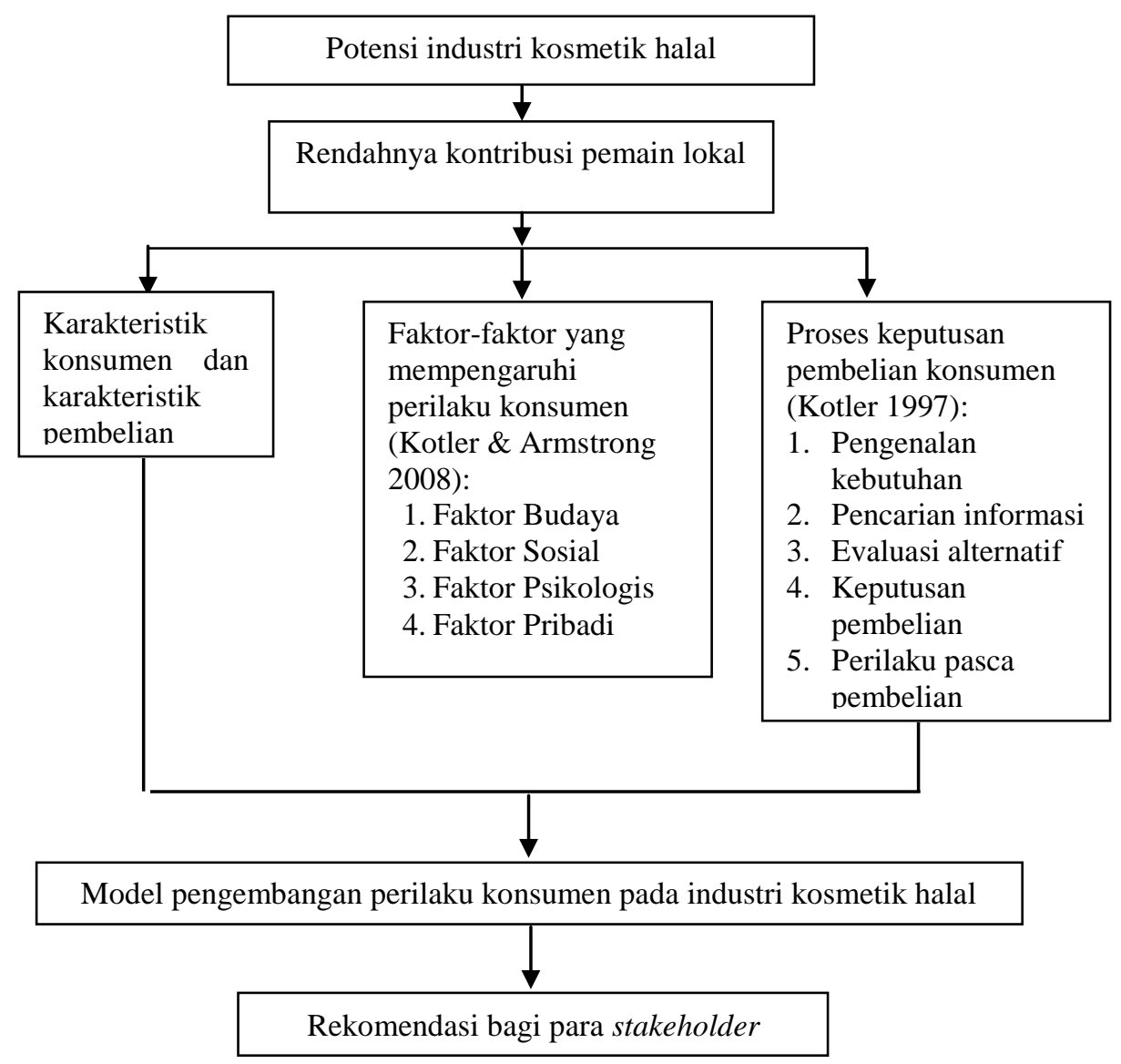

Jurnal Manajemen dan Organisas (JMO),

Vol. 9, No. 1, April 2018, Hal. 59-73

Gambar 2. Kerangka Pemikiran 


\section{Metode Pengumpulan Data}

Penelitian dilakukan di Kota Bogor dengan mempertimbangkan Kota Bogor yang diwacanakan menjadi salah satu kota halal di Indonesia. Waktu penelitian adalah bulan Desember 2017 hingga Februari 2018. Pengumpulan data primer pada penelitian ini dilakukan dengan metode purposive sampling yang mana peneliti menentukan judgment terhadap pemilihan responden agar sesuai dengan target pasar mayoritas industri kosmetik yaitu wanita pekerja. Pendistribusian kuesioner dilakukan secara online untuk mendapatkan data-data faktual dengan lebih efektif dan efisien. Selanjutnya, data tersebut dikelompokkan berdasarkan peubahpeubah yang diteliti lalu dijelaskan kembali diperkuat dengan data-data sekunder dari literatur ilmiah yang relevan. Berdasarkan data BPS (Badan Pusat Statistik) penduduk wanita yang bekerja di Kota Bogor dengan kelompok umur mulai dari 15 tahun hingga lebih dari 65 tahun adalah sebanyak 107.776 (BPS 2015). Dengan menggunakan rumus Slovin yang tingkat error 10 persen maka sampel penelitian adalah 100 wanita pekerja di Kota Bogor.

\section{Metode Pengolahan dan Analisis Data}

Data primer penelitian kemudian diolah dengan teknik analisis deskriptif untuk melihat sebaran frekuentif pada karakteristik konsumen. Sedangkan untuk menyusun model pengembangan perilaku konsumen kosmetik halal menggunakan analisis Structural Equation Modeling (SEM) dengan pendekatan Partial Least Squares (PLS). Menurut Ghozali et al. (2005), SEM merupakan suatu teknik analisis statistik multivariat, yang memungkinkan peneliti untuk menguji pengaruh langsung dan tidak langsung antara variabel yang kompleks, baik recursive maupun non-recursive untuk memperoleh gambaran menyeluruh mengenai suatu model. Hasil pengolahan data menggunakan analisis SEM akan menunjukkan faktor mana yang paling besar pengaruhnya terhadap keputusan pembelian kosmetik halal.

\section{Operasionalisasi Variabel}

Metode analisis SEM menguji pengaruh antara variabel laten. Sebagaimana diketahui variabel laten merupakan konstruk yang luas sehingga membutuhkan indikator-indikator dalam menjelaskannya. Operasionalisasi variabel merupakan kegiatan menguraikan variabel menjadi sejumlah indikator yang menunjuk langsung pada hal-hal yang diukur. Secara lebih rinci operasionalisasi masing-masing variabel dalam penelitian ini ditunjukkan pada Tabel 1 berikut.

Jurnal Manajemen dan Organisasi (JMO),

Vol. 9, No. 1, April 2018, Hal. 59-73

Tabel 1. Operasionalisasi Variabel

\begin{tabular}{|c|c|c|c|}
\hline Variabel & Sub variabel & Deskripsi & Indikator \\
\hline $\begin{array}{l}\text { Perilaku } \\
\text { Konsumen } \\
(\mathrm{X}) \\
\text { Definisi: } \\
\text { Perilaku } \\
\text { pembelian } \\
\text { konsumen }\end{array}$ & $\begin{array}{l}\text { Faktor } \\
\text { Budaya } \\
\text { (BDY) }\end{array}$ & $\begin{array}{l}\text { Budaya adalah determinan } \\
\text { dasar keinginan dan perilaku } \\
\text { seseorang. Dalam budaya } \\
\text { terdapat sub budaya dan kelas } \\
\text { sosial yang memberikan } \\
\text { identifikasi dan sosialisasi yang } \\
\text { lebih spesifik (Kotler dan } \\
\text { Keller 2009) }\end{array}$ & $\begin{array}{l}\text { 1. Tren kosmetik halal } \\
\text { (BDY.1) } \\
\text { 2. Gengsi atau prestige } \\
\text { (BDY.2) }\end{array}$ \\
\hline $\begin{array}{l}\text { mengacu pada } \\
\text { perilaku } \\
\text { pembelian } \\
\text { konsumen akhir } \\
\text { perorangan dan } \\
\text { rumah tangga } \\
\text { yang membeli } \\
\text { barang dan jasa } \\
\text { untuk konsumsi } \\
\text { pribadi (Kotler } \\
\text { dan Armstrong } \\
\text { 2008) }\end{array}$ & $\begin{array}{l}\text { Faktor Sosial } \\
\text { (SOS) }\end{array}$ & $\begin{array}{l}\text { Perilaku konsumen dipengaruhi } \\
\text { oleh faktor-faktor sosial berupa } \\
\text { kelompok kecil, keluarga, peran } \\
\text { dan status sosial konsumen } \\
\text { (Kotler dan Keller 2009) }\end{array}$ & $\begin{array}{l}\text { 3. Pengaruh teman (SOS.1) } \\
\text { 4. Saran keluarga (SOS.2) } \\
\text { 5. Status sebagai wanita karir } \\
\text { (SOS.3) }\end{array}$ \\
\hline
\end{tabular}




\begin{tabular}{|c|c|c|c|}
\hline Variabel & Sub variabel & Deskripsi & Indikator \\
\hline $\begin{array}{l}\text { Perilaku } \\
\text { Konsumen } \\
(\mathrm{X}) \\
\text { Definisi: } \\
\text { Perilaku } \\
\text { pembelian } \\
\text { konsumen } \\
\text { mengacu pada } \\
\text { perilaku }\end{array}$ & $\begin{array}{l}\text { Faktor } \\
\text { Pribadi } \\
(\mathrm{PRB})\end{array}$ & $\begin{array}{l}\text { Karakteristik pribadi yang } \\
\text { melekat pada setiap individu } \\
\text { yang mempengaruhi keputusan } \\
\text { pembelian yaitu berupa usia dan } \\
\text { siklus hidup, pekerjaan, keadaan } \\
\text { ekonomi, gaya hidup, } \\
\text { kepribadian dan konsep diri } \\
\text { (Kotler dan Armstrong (2008) }\end{array}$ & $\begin{array}{l}\text { 6. Usia (PRB.1) } \\
\text { 7. Jenis pekerjaan (PRB.2) } \\
\text { 8. Besar pengeluaran (PRB.3) } \\
\text { 9. Gaya hidup (PRB.4) } \\
\text { 10. Keyakinan terhadap } \\
\text { kualitas kosmetik halal } \\
\text { (PRB.5) } \\
\text { 11. Pengetahuan terhadap } \\
\text { kehalalan produk kosmetik } \\
\text { (PRB.6) }\end{array}$ \\
\hline $\begin{array}{l}\text { pembelian } \\
\text { konsumen akhir } \\
\text { perorangan dan } \\
\text { rumah tangga } \\
\text { yang membeli } \\
\text { barang dan jasa } \\
\text { untuk konsumsi } \\
\text { pribadi (Kotler } \\
\text { dan Armstrong } \\
\text { 2008) }\end{array}$ & $\begin{array}{l}\text { Faktor } \\
\text { Psikologis } \\
\text { (PSI) }\end{array}$ & $\begin{array}{l}\text { Keputusan pembelian konsumen } \\
\text { dipengaruhi oleh faktor } \\
\text { psikologis yaitu motivasi, } \\
\text { persepsi, pembelajaran, dan } \\
\text { keyakinan dan sikap. }\end{array}$ & $\begin{array}{l}\text { 12. } \text { Kebutuhan penggunaan } \\
\text { produk halal menjadi } \\
\text { motivasi membeli (PSI.1) } \\
\text { 13. Citra produk kosmetik } \\
\text { halal (PSI.2) } \\
\text { 14. Pengalaman dalam } \\
\text { penggunaan produk } \\
\text { kosmetik halal (PSI.3) } \\
\text { 15. Label halal meyakinkan } \\
\text { keamanan } \\
\text { (PSI.4) }\end{array}$ \\
\hline $\begin{array}{l}\text { Keputusan } \\
\text { Pembelian (Y) } \\
\text { Keputusan } \\
\text { pembelian }\end{array}$ & $\begin{array}{l}\text { Pengenalan } \\
\text { kebutuhan }\end{array}$ & $\begin{array}{l}\text { Pengenalan kebutuhan akan } \\
\text { terjadi ketika ada } \\
\text { ketidaksesuaian antara keadaan } \\
\text { aktual dengan keadaan yang } \\
\text { diinginkan (Engel et. al 1995). }\end{array}$ & $\begin{array}{l}\text { 1. Label halal menjadi } \\
\text { kebutuhan saat membeli } \\
\text { kosmetik (BELI.1) } \\
\text { 2. Pencarian informasi } \\
\text { mengenai kehalalan produk }\end{array}$ \\
\hline $\begin{array}{l}\text { merupakan } \\
\text { bentuk tindakan } \\
\text { membeli yang } \\
\text { muncul dari } \\
\text { beberapa }\end{array}$ & $\begin{array}{l}\text { Pencarian } \\
\text { informasi }\end{array}$ & $\begin{array}{l}\text { Pencarian informasi merupakan } \\
\text { kegiatan konsumen untuk } \\
\text { pengumpulan informasi melalui } \\
\text { berbagai sumber (Engel et. al } \\
\text { 1995). }\end{array}$ & $\begin{array}{l}\text { kosmetik (BELI.2) } \\
\text { 3. } \begin{array}{l}\text { Menilai kinerja } \\
\text { alternatif yang dipilih } \\
\text { (BELI.3) }\end{array} \\
\text { 4. } \text { Membandingkan kinerja }\end{array}$ \\
\hline $\begin{array}{l}\text { tahapan. Kotler } \\
(1997) \text { membagi } \\
\text { keputusan } \\
\text { pembelian pada } \\
\text { beberapa tahap }\end{array}$ & $\begin{array}{l}\text { Evaluasi } \\
\text { alternatif }\end{array}$ & $\begin{array}{l}\text { Engel et. al (1995) menyatakan } \\
\text { bahwa pada tahapan evaluasi } \\
\text { alternatif terdapat penilaian } \\
\text { terhadap kinerja dari alternatif } \\
\text { yang dipertimbangkan. }\end{array}$ & $\begin{array}{l}\text { kosmetik halal yang dipilih } \\
\text { dengan lainnya (BELI.4) } \\
\text { 5. Pembelian kosmetik halal } \\
\text { (BELI.5) } \\
\text { 6. Kepuasan kosmetik halal }\end{array}$ \\
\hline $\begin{array}{l}\text { yaitu: } \\
\text { pengenalan } \\
\text { kebutuhan, } \\
\text { pencarian } \\
\text { informasi, }\end{array}$ & $\begin{array}{l}\text { Keputusan } \\
\text { membeli }\end{array}$ & \begin{tabular}{lrr}
\multicolumn{2}{l}{ Keputusan membeli } & adalah \\
proses pembelian nyata yang \\
terjadi setelah & melalui \\
serangkaian & tahapan \\
sebelumnya. & & \\
\end{tabular} & \\
\hline $\begin{array}{l}\text { evaluasi } \\
\text { alternatif, } \\
\text { keputusan } \\
\text { pembelian dan } \\
\text { perilaku pasca } \\
\text { pembelian. }\end{array}$ & $\begin{array}{l}\text { Perilaku } \\
\text { pasca } \\
\text { pembelian }\end{array}$ & $\begin{array}{l}\text { Pada tahapan ini dihasilkan } \\
\text { kepuasan atau ketidakpuasan } \\
\text { yang akan mempengaruhi } \\
\text { perilaku selanjutnya terkait } \\
\text { peluang membeli (Kotler 1997). }\end{array}$ & \\
\hline
\end{tabular}

Penelitian ini menganalisis pengaruh variabel laten eksogen yaitu faktor budaya, pribadi, sosial dan psikologis terhadap variabel laten endogen yaitu keputusan pembelian. Sehingga, hipotesis pada penelitian ini antara lain adalah:

H1: Terdapat pengaruh signifikan antara faktor Pribadi terhadap Pembelian kosmetik halal

H2: Terdapat pengaruh signifikan antara faktor Budaya terhadap Pembelian kosmetik halal

H3: Terdapat pengaruh signifikan antara faktor Sosial terhadap Pembelian kosmetik halal

H4: Terdapat pengaruh signifikan antara faktor Psikologis terhadap Pembelian kosmetik halal.

Jurnal Manajemen dan Organisas (JMO),

Vol. 9, No. 1, April 2018, Hal. 59-73 


\section{HASIL DAN PEMBAHASAN}

\section{Profil Konsumen}

Berdasarkan hasil penelitian maka didapatkan karakteristik responden berdasarkan usia, pendidikan terakhir, pekerjaan, pendapatan, pengeluaran rata-rata untuk kosmetik, dan frekuensi pembelian kosmetik. Sebaran karakteristik responden lebih lengkap dapat dilihat pada Tabel 2.

Tabel 2. Profil Konsumen

\begin{tabular}{|c|c|c|}
\hline Karakteristik & Kelompok & Persentase $(\%)$ \\
\hline \multirow[t]{5}{*}{ Usia } & $15-19$ & 1 \\
\hline & $20-24$ & 69 \\
\hline & $25-29$ & 20 \\
\hline & $30-34$ & 5 \\
\hline & $35-39$ & 5 \\
\hline Subtotal & & 100 \\
\hline \multirow[t]{4}{*}{ Pendidikan terakhir } & SMA & 9 \\
\hline & D3 & 46 \\
\hline & S1 & 42 \\
\hline & $\mathrm{S} 2$ & 3 \\
\hline Subtotal & & 100 \\
\hline \multirow[t]{3}{*}{ Pekerjaan } & Pegawai Swasta & 75 \\
\hline & Pegawai Negeri & 15 \\
\hline & Wirausaha & 10 \\
\hline Subtotal & & 100 \\
\hline \multirow[t]{3}{*}{ Pendapatan per bulan } & Dibawah 3 juta rupiah & 26 \\
\hline & 3 juta -6 juta rupiah & 71 \\
\hline & Diatas 6 juta rupiah & 3 \\
\hline Subtotal & & 100 \\
\hline \multirow{5}{*}{$\begin{array}{l}\text { Pengeluaran rata-rata bulanan } \\
\text { untuk kosmetik }\end{array}$} & $50-100$ ribu & 26 \\
\hline & $101-200$ ribu & 43 \\
\hline & $201-300$ ribu & 21 \\
\hline & $301-400$ ribu & 3 \\
\hline & $401-500$ ribu & 7 \\
\hline Subtotal & & 100 \\
\hline \multirow{3}{*}{$\begin{array}{l}\text { Frekuensi pembelian } \\
\text { per tahun }\end{array}$} & $1-5$ kali & 37 \\
\hline & $6-11$ kali & 40 \\
\hline & $12-15$ kali & 23 \\
\hline Subtotal & & 100 \\
\hline
\end{tabular}

Sumber : Data diolah (2018)

Sebagian besar responden berusia 20 tahun sampai 24 tahun dengan tingkat pendidikan yang sangat baik yakni mayoritas D3 (46\%) serta S1 (42\%). Sebanyak 75 persen responden bekerja sebagai pegawai swasta. Penggunaan kosmetik bagi karyawan swasta menjadi hal yang perlu dilakukan mengingat culture perusahaan swasta mengharuskan karyawannya memperhatikan penampilan. Berdasarkan pendapatan, mayoritas responden memiliki selang pendapatan antara $\operatorname{Rp} 3.100 .000,--\operatorname{Rp} 6.000 .000$,- dengan persentase $71 \%$, hal tersebut sesuai dengan UMK (Upah Miminum Kota/Kabupaten) Bogor yaitu Rp 3.599.357,-. Secara umum pengeluaran rata-rata yang dibelanjakan responden untuk pembelian kosmetik berada pada rentang $\mathrm{Rp}$ 50.000,- - Rp 300.000,- setiap bulannya. Pengeluaran bulanan tersebut menggambarkan daya beli responden yang termasuk pada kategori segmen middle class customer. Selanjutnya, berdasarkan data mengenai frekuensi pembelian kosmetik setiap tahunnya diketahui bahwa mayoritas responden melakukan 6 sampai 11 kali pembelian (40\%), hal ini menunjukkan bahwa kosmetik termasuk kebutuhan rutin setiap bulannya bagi sebagian besar responden. 


\section{Karakteristik Pembelian Kosmetik Halal}

Berdasarkan karakteristik responden pada Tabel 2, maka dapat disimpulkan bahwa responden dalam penelitian ini merupakan konsumen segmen kelas menengah. Hasil penelitian Ahmed dan Mateen Khan (2016) menunjukkan bahwa beberapa negara seperti Argentina, Brazil, Chile, China, Colombia, Mesir, India, Indonesia, Rusia dan Meksiko memiliki konsumen segmen menengah yang tumbuh dengan cepat. Sekitar $48 \%$ dari total populasi penduduk Indonesia merupakan masyarakat kelas menengah yang berkontribusi pada $44 \%$ total belanja fast moving consumer goods (SWA 2012) termasuk untuk produk kosmetik.

Penelitian ini juga membahas lebih lanjut mengenai karakteristik pembelian kosmetik halal (Tabel 3). Hasil pengolahan data menunjukkan bahwa mayoritas responden menggunakan kosmetik merek Wardah $(23,54 \%)$. Wardah merupakan pioneer kosmetik halal yang ditargetkan bagi konsumen kelas menengah. Citra produk halal yang melekat pada merek Wardah membuat konsumennya memiliki keyakinan bahwa produk ini sehat dan aman untuk digunakan dalam jangka panjang. Hal ini terlihat dari data bahwa ketika merek kosmetik yang biasa digunakan tidak tersedia di toko, maka mayoritas responden (63\%) akan tetap mencari merek yang sama di toko lain. Di sisi lain, konsumen segmen menengah ini memiliki karakteristik yang unik dimana sebanyak 78 persen responden akan tetap membeli merek yang sama meskipun harga merek produk tersebut mengalami kenaikan. Konsumen segmen menengah merupakan pasar yang prospektif karena mereka fokus melakukan pembelian produk yang mampu meningkatkan taraf hidupnya. Konsumen pada segmen ini bersedia membayar lebih untuk membeli produk-produk dengan mempertimbangkan kualitas.

Tabel 3. Karakteristik Pembelian Kosmetik Halal

\begin{tabular}{|c|c|c|}
\hline Karakteristik & Kelompok & Persentase $(\%)$ \\
\hline Jika merek kosmetik yang & Cari ke toko lain & 63 \\
\hline biasa digunakan tidak tersedia & Beli merek produk lain sejenis & 19 \\
\hline & Tidak jadi membeli & 18 \\
\hline Subtotal & & 100 \\
\hline Jika merek harga kosmetik & Tetap membeli merek yang sama & 78 \\
\hline yang biasa digunakan naik & Membeli merek produk lain sejenis & 22 \\
\hline Subtotal & & 100 \\
\hline Merek kosmetik & 1.Wardah* & 23,54 \\
\hline digunakan & 2.Maybelline & 11,11 \\
\hline & 3.Make Over* & 9,79 \\
\hline & 4.Purbasari* & 9,79 \\
\hline & 5.Emina* & 7,94 \\
\hline & 6.Revlon & 6,35 \\
\hline & 7.NYX & 5,82 \\
\hline & 8.Sariayu* & 4,76 \\
\hline & 9.Pixy* & 3,44 \\
\hline & 10.Mustika Ratu* & 3,17 \\
\hline & 11.Merek Lainnya & 14.29 \\
\hline
\end{tabular}

Subtotal

100

Keterangan: *Kosmetik berlabel halal

Sumber: Data diolah (2018)

Selain membahas mengenai karakteristik konsumen, penelitian ini juga mengkaji alasan konsumen ketika membeli konsmetik berlabel halal. Responden diberikan pertanyaan untuk memberikan tiga alasan mereka saat membeli kosmetik halal mulai dari alasan yang sangat penting, cukup penting dan kurang penting (Gambar 3). Dari hasil penelitian ini didapatkan bahwa faktor yang paling penting yang dipertimbangkan konsumen untuk membeli produk kosmetik halal adalah faktor harga (23\%). Meskipun demikian, uniknya sebagian besar konsumen akan tetap melakukan pembelian terhadap merek kosmetik yang sama ketika harganya naik. Kenaikan harga produk yang dapat diterima bagi mereka tentunya sesuai atau tidak melebihi pengeluaran maksimal per bulannya untuk produk kosmetik yaitu Rp 50.000,-Rp 300.000,-. Jika kenaikan harga produk melebihi pengeluarannya, konsumen memiliki kemungkinan untuk berpindah membeli produk sejenis ke merek lain. Sehingga, dapat disimpulkan bahwa konsumen cenderung loyal dengan merek produk kosmetik yang biasa

Jurnal Manajemen dan Organisasi (JMO), Vol. 9, No. 1, April 2018, Hal. 59-73 
dibeli selama harga yang diberikan sesuai dengan daya belinya. Hal ini dapat dimengerti mengingat konsumen segmen menengah termasuk konsumen yang cerdas, mereka cenderung mengkombinasikan kenyamanan dan penawaran dari channel ritel tradisional yang menawarkan harga hemat dengan channel modern yang menawarkan keragaman produk (SWA 2012). Di sisi lain faktor yang cukup penting yang dipilih adalah kualitas disusul dengan merek sebagai faktor yang dipertimbangkan paling terakhir yang dipentingkan oleh konsumen dalam pembelian kosmetik halal.

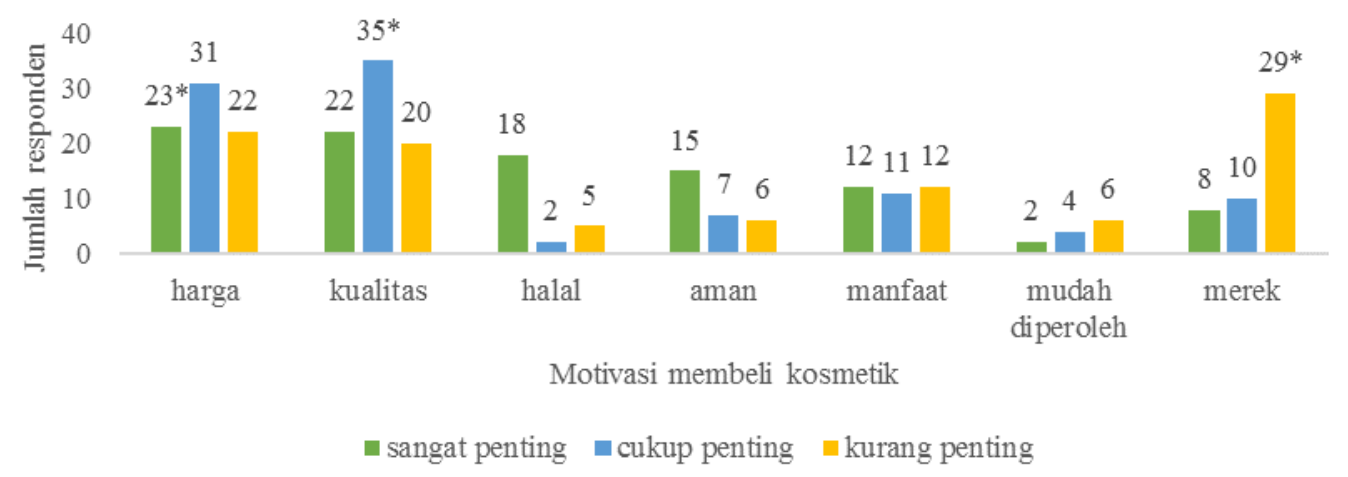

Keterangan : $*$ nilai tertinggi untuk masing-masing kategori

Gambar 3. Motivasi membeli kosmetik halal

Sumber: Data diolah (2018)

Jurnal Manajemen dan Organisasi (JMO),

Vol. 9 , No. 1, April 2018, Hal. 59-73

\section{Model Pengembangan Perilaku Konsumen Produk Kosmetik Halal}

Penelitian ini menggunakan analisis SEM dengan kategori variance based. Pada variance based SEM (VBSEM) dilakukan pendekatan partial least squares (PLS) yang bertujuan untuk mencari hubungan linear prediktif antar variabel (Ghozali 2008). Grand concept yang dijadikan acuan penelitian ini adalah kajian literatur Kotler (1997) yang menjelaskan bahwa faktor-faktor yang berpengaruh pada perilaku konsumen adalah faktor kebudayaan, faktor sosial, faktor personal, dan faktor psikologi. Variabel laten dalam penelitian ini terdiri dari empat variabel eksogen yaitu faktor kebudayaan, faktor pribadi, fakor sosial dan faktor psikologis, serta satu variabel endogen yaitu keputusan pembelian. Setiap variabel laten memiliki masing-masing variabel manifest (indikator) yang merefleksikan kontribusinya pada variabel laten.

\section{Analisis Outer Model}

Model pengukuran (outer model) adalah model yang mendefinisikan bagaimana setiap indikator berhubungan dengan variabel latennya. Evaluasi outer model dilakukan terhadap konstruk yang direfleksikan oleh indikator-indikatornya. Ukuran refleksif indikator dengan konstruknya dikatakan tinggi jika memiliki nilai loading factor lebih dari 0,7 sehingga indikator yang memiliki nilai loading factor kurang dari 0,7 didrop atau dihapus. Dikarenakan semua indikator dalam model berbentuk reflektif, maka analisis model outer termasuk pada mode reflektif. Pengujian mode reflektif terlebih dahulu dilakukan dengan menggunakan 5 kriteria yaitu: Loading factor, Composite Reliability, Average Variance Extracted (AVE), Akar kuadrat AVE, dan Cross Loading (Ghozali 2008). Berdasarkan tabel berikut, diketahui bahwa outer model reflektif penelitian ini telah memenuhi nilai standar yang ada, baik dalam kriteria reliabilitas dan validitas. 
Tabel 4. Hasil Penilaian Kriteria dan Standar Nilai Mode Reflektif

\begin{tabular}{|c|c|c|c|}
\hline Kriteria & Penjelasan & Standar & Hasil penilaian \\
\hline Loading factor & $\begin{array}{l}\text { Kekuatan indikator dalam } \\
\text { merefleksikan laten }\end{array}$ & $\geq 0,7$ & $\begin{array}{l}\text { Semua indikator memiliki } \\
\text { loading factor } \geq 0,7\end{array}$ \\
\hline Kriteria & Penjelasan & Standar & Hasil penilaian \\
\hline $\begin{array}{l}\text { Composite } \\
\text { Reliability }\end{array}$ & Konsistensi internal & $>0,6$ & $\begin{array}{l}\text { BUDAYA }=1,000 ; \\
\text { PEMBELIAN }=1,000 ; \\
\text { PRIBADI = 0,898; } \\
\text { PSIKOLOGIS }=0,955 ; \\
\text { SOSIAL }=0,858\end{array}$ \\
\hline $\begin{array}{l}\text { Average } \\
\text { Variance } \\
\text { Extracted (AVE) }\end{array}$ & Validitas konstruk & $>0,5$ & $\begin{array}{l}\text { BUDAYA = } 1,000 ; \\
\text { PEMBELIAN = } 1,000 ; \\
\text { PRIBADI = 0,691; } \\
\text { PSIKOLOGIS = 0,841; } \\
\text { SOSIAL }=0,752\end{array}$ \\
\hline $\begin{array}{l}\text { Akar kuadrat } \\
\text { AVE }\end{array}$ & Validitas diskriminan & $\begin{array}{l}\text { Lebih besar dari nilai } \\
\text { korelasi antar variabel }\end{array}$ & $\begin{array}{l}\text { Semua nilai akar kuadrat } \\
\text { AVE dari peubah laten, lebih } \\
\text { besar dari korelasi peubah } \\
\text { laten lainnya (Latent Variable } \\
\text { Correlation) }\end{array}$ \\
\hline Cross Loading & Validitas diskriminan & $\begin{array}{l}\text { Setiap indikator } \\
\text { memiliki loading lebih } \\
\text { tinggi untuk setiap } \\
\text { laten yang diukur, } \\
\text { dibandingkan dengan } \\
\text { indikator untuk laten } \\
\text { lainnya }\end{array}$ & $\begin{array}{l}\text { Semua indikator dari variabel } \\
\text { laten memiliki korelasi yang } \\
\text { lebih besar pada laten sendiri } \\
\text { daripada korelasi ke laten } \\
\text { lainnya (Cross loading) }\end{array}$ \\
\hline
\end{tabular}

Sumber: Data diolah (2018)

\section{Analisis Inner Model}

Model struktural atau inner model adalah model yang menggambarkan signifikansi hubungan dan pengaruh antar variabel laten, yaitu peubah Budaya, Sosial, Psikologis, Pribadi terhadap Pembelian. Proses untuk mendapatkan inner model dilakukan melalui teknik bootstrapping dengan Smart PLS. Teknik bootstrapping adalah teknik rekalkulasi data sampel secara random untuk memperoleh nilai T-statistik. Berdasarkan nilai T-statistik yang diperoleh, maka dapat diketahui hubungan antar variabel yang diukur. Selanjutnya, besarnya pengaruh antar variabel dapat dilihat dari kriteria estimasi koefisien jalur untuk masing-masing path yang ada. Hasilnya menunjukkan bahwa hanya faktor Psikologis yang berpengaruh nyata pada model, dimana memiliki nilai T-statistik lebih besar dari T-tabel $(1,96)$. Selanjutnya, jika dilihat dari nilai $\mathrm{R}^{2}$ model penelitian tergolong model substansial karena memiliki nilai $\mathrm{R}^{2}$ sebesar $67,2 \%$. Hal ini berarti variabilitas laten keputusan Pembelian dapat dijelaskan oleh variabel Budaya, Pribadi, Sosial dan Psikologis sebesar 67,2\% dan sisanya dijelaskan oleh variabel lain di luar penelitian. Hasil analisis inner model selengkapnya dapat dilihat pada tabel berikut.

Tabel 5. Nilai Analisis Model Inner vs Standar

\begin{tabular}{|c|c|c|c|}
\hline Kriteria & Penjelasan & Standar & Hasil penilaian \\
\hline $\begin{array}{l}\mathrm{R}^{2} \text { dari } \\
\text { peubah laten } \\
\text { endogen }\end{array}$ & $\begin{array}{l}\text { Variabilitas konstruk } \\
\text { endogen yang } \\
\text { dijelaskan oleh } \\
\text { variabilitas konstruk } \\
\text { eksogen }\end{array}$ & $\begin{array}{l}\text { Chin (1998) } \\
\text { mengelompokkan nilai } \\
\mathrm{R}^{2} \text { sebesar 0,67; 0,33; } \\
\text { dan 0,19 sebagai } \\
\text { "substansial", "moderat" } \\
\text { dan "lemah", }\end{array}$ & $\mathrm{R}^{2}$ untuk Pembelian $=0,672$ \\
\hline
\end{tabular}

Jurnal Manajemen dan Organisasi (JMO),

Vol. 9, No. 1, April 2018, Hal. 59-73 


\begin{tabular}{lllll}
\hline \multicolumn{1}{c}{ Kriteria } & Penjelasan & \multicolumn{1}{c}{ Standar } & \multicolumn{2}{c}{ Hasil penilaian } \\
\hline Estimasi & Evaluasi & Pengaruh nyata & Nilai T-statistik: & Nilai koefisien jalur: \\
koefisien & terhadap nilai & jika, T-statistik $>$ & & \\
jalur & koefisien, & T-tabel. Pada & Budaya $\rightarrow$ Pembelian & Budaya $\rightarrow$ Pembelian \\
& meliputi & alpha 5 persen, & 0,595 & $-0,040$ \\
& pengaruh nyata & nilai T-tabel & Pribadi $\rightarrow$ Pembelian & Pribadi $\rightarrow$ Pembelian \\
& dan nilai & adalah 1,96 & 1,868 & 0,246 \\
& koefisien jalur & & Sosial $\rightarrow$ Pembelian & Sosial $\rightarrow$ Pembelian - \\
& & & 0,057 & 0,004 \\
& & & Psikologis $\rightarrow$ & Psikologis $\rightarrow$ \\
& & & Pembelian 5,115 & Pembelian 0,603 \\
\hline
\end{tabular}

Sumber: Data primer diolah (2018)

\section{Pengaruh faktor Pribadi terhadap Pembelian kosmetik halal}

Pengaruh antara faktor Pribadi terhadap keputusan Pembelian menghasilkan nilai Tstatistik sebesar 0,246 lebih kecil dari T-tabel yakni 1,960. Maka hipotesis pertama (H1) penelitian ditolak. Berdasarkan model akhir SEM faktor Pribadi dicerminkan oleh 4 indikator utama yaitu PRB.2 dengan loading factor sebesar 0,705, PRB.3 sebesar 0,775, PRB.5 sebesar 0,917, dan PRB.6 sebesar 0,908. Penelitian yang dilakukan oleh Briliana dan Noviana (2016) menunjukkan bahwa pengetahuan berkontribusi positif pada perilaku konsumen. Hal ini sesuai dengan hasil penelitian dimana indikator pengetahuan terhadap kehalalan produk (PRB.5) menjadi karakteristik yang paling dominan mencerminkan laten Pribadi. Melalui pengetahuan yang baik, maka konsumen akan semakin yakin terhadap kualitas kosmetik halal (PRB.6). Di samping itu, jenis pekerjaan (PRB.2) dan besarnya pengeluaran (PRB.3) juga berperan penting dalam menggambarkan laten Pribadi konsumen.

\section{Pengaruh faktor Budaya terhadap Pembelian kosmetik halal}

Hasil pengolahan data menunjukkan bahwa tidak terdapat pengaruh signifikan antara faktor Budaya terhadap keputusan pembelian kosmetik halal, dengan nilai T- statistik sebesar 0,595 lebih kecil dari nilai T-tabel $(1,960)$. Sehingga hipotesis kedua (H2) penelitian ini ditolak. Model akhir pada gambar berikut menunjukkan bahwa, variabel laten budaya paling besar interelasinya dicerminkan oleh indikator BDY.1 $(1,000)$ yaitu membeli kosmetik berlabel halal karena mengikuti tren saat ini. Tren menjadi indikator paling besar yang mencerminkan faktor budaya dalam pembelian kosmetik berlabel halal. Tren dibentuk dari beberapa nilai (values) yang ada. Pada Global Halal Industry Overview dinyatakan bahwa nilai-nilai yang terdapat pada kosmetika halal antara lain adalah social responsibility, stewardship of the earth, economic and social justice, animal welfare dan ethical investment. Nilai-nilai positif pada produk halal membuat pasar industri halal memiliki cakupan pasar yang luas tidak hanya eksklusif pada konsumen Muslim saja. Seiring dengan peningkatan kesadaran nilai-nilai positif tersebut maka tren menggunakan kosmetik halal juga semakin meningkat.

Jurnal Manajemen dan Organisasi (JMO), Vol. 9, No. 1, April 2018, Hal. 59-73

\section{Pengaruh faktor Sosial terhadap Pembelian kosmetik halal}

Hal serupa juga terjadi pada pengaruh antara faktor Sosial terhadap keputusan Pembelian kosmetik halal. Jalur pengaruh ini menghasilkan nilai T-statistik sebesar 0,004 lebih kecil dari T-tabel yakni 1,960. Maka hipotesis ketiga (H3) penelitian ditolak. Berdasarkan model akhir SEM faktor Sosial dicerminkan oleh 2 indikator utama yaitu saran keluarga (SOS.2) dan status sebagai wanita karir (SOS.3). Berdasarkan nilai loading factor diketahui bahwa selain saran dari keluarga, status sebagai wanita karir menjadi indikator paling dominan dalam mencerminkan laten Sosial. Sebagaimana telah dibahas sebelumnya bagi sebagian besar wanita karir penggunaan kosmetik menjadi suatu kebutuhan karena dapat menunjang penampilan yang menarik saat bekerja.

\section{Pengaruh faktor Psikologis terhadap Pembelian kosmetik halal}

Kotler dan Armstrong (2008) menyatakan bahwa keputusan pembelian konsumen dipengaruhi oleh faktor psikologis yaitu motivasi, persepsi, pembelajaran, dan keyakinan dan sikap. Penelitian ini menunjukkan hasil yang selaras dimana faktor Psikologis berpengaruh 
signifikan terhadap Keputusan Pembelian karena memiliki nilai T-hitung sebesar 5,115 lebih besar dari nilai T-tabel sehingga hipotesis keempat $(\mathrm{H} 4)$ diterima. Besarnya pengaruh laten eksogen terhadap laten endogen dapat dilihat dari besaran nilai koefisien jalur. Diketahui bahwa variabel laten Psikologis memiliki pengaruh positif langsung terhadap Pembelian, dengan koefisien jalur sebesar 0,603. Faktor psikologis menjadi faktor yang berpengaruh pada pembelian kosmetik berlabel halal dikarenakan produk kosmetik merupakan produk yang penggunaannya dikonsumsi secara personal dimana merek kosmetik halal yang digunakan mampu menunjukkan pemenuhan kebutuhan pengakuan ataupun penghargaan bagi konsumen.

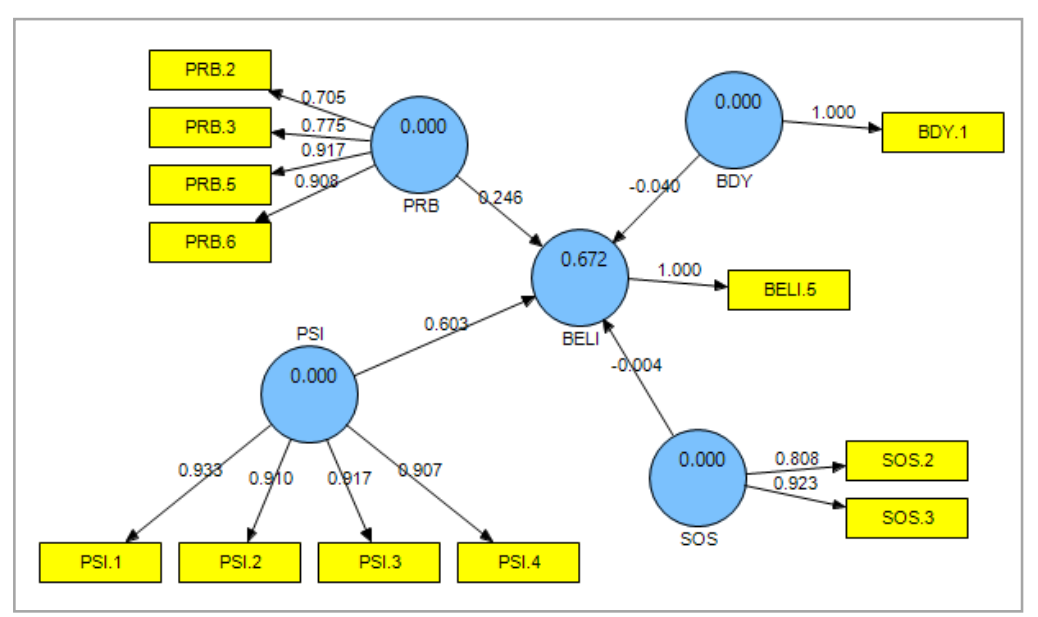

Gambar 4. Model akhir penelitian SEM

Berdasarkan gambar model akhir penelitian analisis SEM, faktor Psikologis memiliki empat indikator utama yaitu kebutuhan penggunaan produk halal menjadi motivasi membeli (PSI.1), citra produk kosmetik halal (PSI.2), pengalaman dalam penggunaan produk kosmetik halal (PSI.3) dan label halal meyakinkan keamanan kosmetik (PSI.4). Semua indikator yang merefleksikan laten Psikologis memiliki nilai loading factor lebih dari 0,9 sehingga sangat besar kontribusinya dalam menggambarkan latennya. Sesuai dengan hasil yang diperoleh pada outer model, kebutuhan menggunakan produk halal menjadi indikator yang paling besar dalam mencerminkan faktor psikologis. Hal ini berarti kesadaran konsumen terhadap pentingnya mengkonsumsi produk halal (termasuk kosmetik halal) sudah pada level yang baik sesuai dengan mayoritas responden yang tergolong pada kelompok dengan tingkat pendidikan yang tinggi. Hasil ini konsisten dengan penelitian Lada dan Amin (2009) yang menyatakan bahwa keputusan untuk membeli produk kosmetik halal ditentukan oleh pengetahuan konsumen terkait produk halal. Pengetahuan yang baik menjadi kunci utama yang mempengaruhi niat beli produk kosmetik halal (Shaari \& Ariffin 2010).

Selanjutnya beberapa indikator seperti citra produk, pengalaman, label halal menjadi hal lain yang juga memainkan peranan penting dalam mencerminkan faktor psikologis konsumen. Besarnya koefisien pengaruh Psikologis terhadap Pembelian dapat diinterpretasikan bahwa semakin baik indikator-indikator dari faktor Psikologis seorang konsumen, maka akan semakin tinggi pula tingkat pembelian produk kosmetik halal. Sehingga pemain industri kosmetika halal sebaiknya menciptakan suatu produk yang tidak hanya berkualitas baik dalam citra kehalalan produknya, tetapi mampu memberikan pengalaman yang berkesan bagi konsumennya agar pembelian produk menjadi kebiasaan bagi konsumen (BELI.5) yang pada akhirnya dapat menjadi long term profitability bagi perusahaan.

Pada penelitian ini pembelian kosmetik halal tidak dipengaruhi secara signifikan oleh faktor Budaya, Sosial, dan Pribadi. Produk kosmetik yang notabene-nya mendukung penampilan wanita lebih besar kontribusinya dalam memenuhi kebutuhan psikologis yang timbul dari kebutuhan akan pengakuan atau penghargaan. Karakteristik produk kosmetik yang termasuk pada produk personal care menjadi salah satu penyebab keputusan pembelian lebih dipengaruhi oleh aspek psikologis individu konsumen. Produk kosmetik merupakan produk yang unik karena setiap individu memiliki tingkat kecocokan yang berbeda pada setiap jenis 
kosmetik. Sehingga pemilihan terhadap merek produk kosmetik lebih ditentukan oleh faktor internal individu konsumen daripada faktor lainnya.

\section{KESIMPULAN}

Secara umum karakteristik konsumen kosmetik halal memiliki tingkat pendidikan yang sangat baik yatu Diploma dan Sarjana yang berprofesi sebagai karyawan swasta. Sebagian besar konsumen tergolong pada segmen middle class customer dengan frekuensi pembelian kosmetik yang cukup regular yaitu 6 sampai 11 kali pembelian kosmetik per tahunnya. Pada pola pembelian konsumen terdapat fenomena yang unik yaitu mayoritas konsumen akan tetap membeli merek yang sama meskipun harga merek produk tersebut mengalami kenaikan dengan mempertimbangkan kualitas. Diketahui bahwa variabel laten Psikologis memiliki pengaruh positif langsung terhadap keputusan Pembelian, dengan koefisien jalur sebesar 0,603. Kebutuhan menggunakan produk halal menjadi indikator yang paling besar dalam mencerminkan faktor psikologis. Secara umum kesadaran konsumen terhadap pentingnya mengonsumsi produk halal (termasuk kosmetik halal) sudah pada level yang baik. Pemain industri kosmetika halal lokal sebaiknya mampu menciptakan produk yang berkualitas dengan pemberian label halal, sehingga dapat meningkatkan citra kehalalan produknya.

\section{DAFTAR PUSTAKA}

Ahmed ME, Khan MM, Samad N. 2016. Income, Social Class and Consumer Behaviour: A Focus on Developing Nations. Journal of Applied Business and Economic Research. 14(10):6679-6702.

BIZTEKA. 2015. Perkembangan Pasar Industri Kosmetik Di Indonesia 2010 - 2015 [internet]. [diunduh 2017 Oktober 13]. Tersedia pada: http://cciindonesia.com/2016/06/17/perkembangan-pasarindustri- kosmetik-di-indonesia-20102015.

[BPS]. Badan Pusat Statistik Kota Bogor. 2016. Penduduk Kota Bogor Menurut Kecamatan dan Jenis Kelamin 2016. Bogor (ID): BPS.

Briliana V, Noviana R. 2016. The Antecedents ad Outcome of Halal Cosmetics Products: A Case Study in Jakarta Indonesia. International Journal of Business, Economics, and Law. 11(2):1-9. ISSN 2289-1552.

Demirel Y, Yasarsoy E. 2017. Exploring Consumer Attitudes Toward Halal Products. Journal of Tourismology. 3(1):34-43.

Jurnal Manajemen dan Organisasi (JMO),

Vol. 9, No. 1, April 2018, Hal. 59-73
Engel JF, Blackwell RD, Miniard PW. 1995. Perilaku Konsumen Jilid 2, Edisi Keenam. Jakarta (ID): Binarupa Aksara.

Ghozali I. 2008. Structural Equation Modelling Metode Alternatif dengan Partial Least Square Edisi 2. Semarang (ID): Badan Penerbit Universitas Diponegoro.

Ghozali I, Latan H. 2015. Structural Equation Modeling Metode Alternatif dengan Partial Least Square 3.0. Semarang (ID): Badan Penerbit Universitas Diponegoro

Handayani MS. 2016. Saat Kosmetik Halal Memimpin Pasar. [diunduh 2017 Oktober 19]. Tersedia pada: https://tirto.id/saat-kosmetik-halal-memimpin-pasar-bP4r.

[Kontan]. News Data Financial Tools. 2017. Produk Kosmetik Domestik Baru Berkontribusi 30\%. [diunduh 2017 Desember 31]. Tersedia pada: https://industri.kontan.co.id/news/produk-kosmetik-domestik-baru berkontribusi-30.

Kotler P, Armstrong G. 2008. Prinsip-Prinsip Pemasaran Edisi Kedua Belas. Jakarta (ID): Erlangga.

Kotler P. 1997. Manajemen Pemasaran Jilid 1, Edisi Bahasa Indonesia. Jakarta (ID): Prenhallindo.

Lada S, Tanakinjal GH, Amin H. 2009. Predicting intention to choose halal products using theory of reasoned action. International Journal of Islamic and Middle Eastern Finance and Management, 2(1):66-76.

Sitinjak T, Sugiarto. 2006. Lisrel. Yogyakarta (ID): Graha Ilmu 
Sumarwan U. 2011. Perilaku Konsumen. Jakarta (ID): PT Ghalia Indonesia

Syalaby A. 2017. Target 2016 Dikebut Tahun ini, DPRD Kota Bogor Usulkan Perda tentang Kota Halal [Internet]. [diunduh 2018 Maret 7]. Tersedia pada:https://tribunnews.com/2017/01/03/target-2016-dikebut-tahun-ini-dprd-kotabogor-usulkan-perda-tentang-kota-halal.

Vol. 9, No. 1, April 2018, Hal. 59-73 